\title{
«La configuración del estado de derecho en España: la realidad normativa en los orígenes del constitucionalismo histórico»"
}

\author{
JoSÉ F. CHOFRE SIRVENT
}

De todos es conocido la gran cantidad de estudios que se han llevado a cabo, desde diferentes enfoques, sobre la Constitución de 1812. Pudiera pensarse que detenerse de nuevo en el análisis de nuestro primer texto constitucional sería una tarea redundante. Sin embargo, a pesar de la abundancia de las investigaciones realizadas, existe un aspecto que es básico y que, sorprendentemente, no ha sido objeto de detenido análisis por los autores. Nos referimos a la configuración del sistema normativo verdaderamente existente durante la vigencia de la Constitución de 1812 .

La cuestión de referencia ha estado permanentemente rodeada de gran confusión tanto en el mismo origen del constitucionalismo como en los tiempos actuales. Por lo que se refiere al origen del constitucionalismo destaca por su especial trascendencia el debate que, recién reinstaurado el régimen constitucional en 1820, se planteó en las Cortes acerca de si será objeto de «ley» («decreto de Cortes con carácter de ley») o de «decreto de Cortes» («decreto de competencia exclusiva de las Cortes») el asunto relacionado acerca de si ha de volver a entrar en la sucesión de la Corona el señor Infante don Francisco de Paula y S.M. doña María Luisa, gran duquesa de Luca.

Y por lo que se refiere a la actualidad téngase presente, que cuando en los años 1810-1814 no es posible, en puridad de conceptos, afirmar que existen «leyes» la mayoría de los autores señalan, sin el menor respeto a las formas jurídicas, que durante el citado período las Cortes ela- 
boraron y aprobaron «leyes» y «decretos»; y otros autores vienen a declarar sin el menor reparo que la «ley» es la norma «primaria y absolutamente incondicional» en el ordenamiento jurídico implantado en Cádiz.

Estas circunstancias, sin duda, vienen a subrayar con mayor énfasis el alto nivel de desconocimiento que existía en la propia época y en los tiempos actuales sobre la verdadera realidad normativa existente durante la vigència de la Constitución de Cádiz, y el desinterés que por parte de la doctrina se le ha dispensado. En la presente tesis doctoral nos hemos ocupado modestamente de evidenciar dicho desconocimiento, así como intentar aportar algunos elementos que contribuyan a clarificar los aspectos confusos que han rodeado, y continúan rodeando, la configuración del referido sistema normativo.

Para alcanzar el objetivo propuesto en la realización del presente estudio, se ha creído conveniente distinguir dos partes, aunque complementarias; en primer lugar, se realiza un análisis formal basado en el examen del cuerpo doctrinal y teórico que subyace a las discusiones parlamentarias y su concreción en el sistema normativo establecido en la Constitución de Cádiz; y, en segundo lugar, se lleva a cabo un análisis material, que se construye exclusivamente ateniéndose a la producción normativa verdaderamente elaborada y aprobada por las Cortes en los diferentes períodos en los que ha estado vigente la Constitución de 1812. Como bien puede observarse, la ausencia de una de ambas perpectivas de análisis dejaría el trabajo incompleto. La complementariedad es, por tanto, ineludible; nos permitirá constatar si el contenido de las disposiciones constitucionales y reglamentarias, así como su conceptualización, son observadas fielmente en la práctica normativa, o si, por el contrario, ésta contradice aquéllas.

Pero es que, además de las dos partes que integran este trabajo y que constituyen el cuerpo principal del mismo, se ha considerado fundamental aportar como pruebas concluyentes de las tesis mantenidas en este estudio un Apéndice en el que se contiene con carácter exhaustivo toda la producción de normas aprobadas por las Cortes durante los períodos 1810-1814, 1820-1823 y 1836-1837. La realización de este Apéndice constituye una novedad de indudable interés al ser la primera codi- 
ficación de todas las normas emanadas por las Cortes en una etapa clave de transición del preconstitucionalismo al constitucionalismo.

Las principales conclusiones que se derivan de esta tesis doctoral son las que a continuación exponemos resumidamente:

Primera.-El nacimiento del sistema constitucional en España va a dar lugar al inicio de un largo proceso que se prolongará hasta 1837 y que producirá finalmente una ruptura total con respecto al Antiguo Régimen. Ruptura que no tiene lugar en su más amplio sentido durante la vigencia de la Constitución de Cádiz, como inicialmente pudiera pensarse, sino a raíz de la aprobación de la Constitución de 1837, que pone fin a la transición de la monarquía absoluta al Estado liberal.

Segunda.-Como consecuencia de la influencia que el Antiguo Régimen vino ejerciendo sobre la configuración del sistema normativo que surgió con la Constitución de Cádiz, es preciso señalar que «la transición del preconstitucionalismo al constitucionalismo» es seguramente la mejor forma de definir, desde la perspectiva jurídico política, el período de referencia. Nos encontramos, pues, en una fase de transición entre un Estado estamental, que se encuentra apurando sus últimos momentos de existencia, y un Estado constitucional, que, superando no pocas e importantes dificultades, lucha por consolidar su situación. En definitiva, pues, el Estado y el Derecho que emerge en los comienzos ael siglo XIX pudiera decirse que suponen un «Orden jurídico-político de transición».

Tercera.-El fin de la transición del Antiguo Régimen al estado constitucional se refleja con carácter definitivo en la distinta configuración del sistema normativo. En otras palabras, con la aprobación de la Constitución de 1837 desaparecen las diferentes clases de «decretos de Cortes», y el Poder legislativo elaborará exclusivamente, como norma única, «leyes», categoría genuina y propia del Estado constitucional.

Cuarta._El modelo de la ley (o más propiamente «decreto de Cortes con carácter de ley», distinguiéndolo de los demás decretos que las Cortes tienen facultad de aprobar) que configura la Constitución de Cádiz, a pesar que las Cortes ocupan una posición de predominio absolu- 
to en la estructura del Estado, no ostenta el valor de norma suprema del ordenamiento jurídico, porque su campo de acción está acotado por las materias reservadas a los «decretos de competencia exclusiva de las Cortes». La ley, por tanto, no lo puede todo, y lo que puede no es lo más importante. Y es más, concurre la significativa circunstancia de que la ley no es expresión directa y exclusiva de la soberanía nacional, ya que para su formación es precisa la concurrencia de la voluntad del Rey y de las Cortes, mientras que, por el contrario, los «decretos de competencia exclusiva de las Cortes» sí expresan auténticamente la voluntad de la nación, al no intervenir el Rey mediante la sanción. 